\title{
Effect of modified atmosphere packaging on the TVB/TMA-producing microflora of cod fillets
}

\author{
J. Debevere*, G. Boskou
}

Department of Food Technolngy and Nutrition, Faculty of Agriculitural and Applied Biological Sciences. University of Ghent, Coupure Links 653, 9000 Ghent, Belgium

Received 28 April 1995; revised 28 November 1995; accepted 31 January 1996

\begin{abstract}
Cod fillets (Gadus morhua) were packed under modified atmospheres, with four different gas compositions $\left(60 \% \mathrm{CO}_{2}-10 \% \quad \mathrm{O}_{2}-30 \% \quad \mathrm{~N}_{2}, 60 \% \quad \mathrm{CO}_{2}-20 \% \quad \mathrm{O}_{2}-20 \% \mathrm{~N}_{2}, 60 \% \mathrm{CO}_{2}\right.$ $30 \% \mathrm{O}_{2}-10 \% \quad \mathrm{~N}_{2}, 60 \% \mathrm{CO}_{2}-40 \% \mathrm{O}_{2}$ ), and stored at $6{ }^{\circ} \mathrm{C}$. Plate counts were carried out after $3,4,5,6$ and 7 days, to follow the growth of aerobic and anaerobic bacteria, lactic acid bacteria, $\mathrm{H}_{2} \mathrm{~S}$-producing bacteria and Enterobacteriaceae. The production of total volatile bases (TVB) and trimethylamine (TMA), and the changes in $\mathrm{pH}$ of the fillets were measured. Modified atmosphere packaging (MAP) had in general an inhibitory effect on the growth of the microflora but limited inhibition of the production of TVB and TMA. Despite the fact that increased oxygen proportions in the atmosphere contributed in a slightly lower production of TMA, all the samples had a TVB and TMA content high enough to be considered as spoiled after 4 days' storage at $6^{\circ} \mathrm{C}$. A total aerobic plate count at $25^{\circ} \mathrm{C}$ of a $10^{6} \mathrm{cfu} / \mathrm{g}$, combined with the presence of only a $10^{3} \mathrm{cfu} / \mathrm{g} \mathrm{of} \mathrm{H}_{2} \mathrm{~S}$-producing bacteria, which are normally considered as TMAO-reducing organisms in fish, cannot explain the strong increase in TMA. A high cell concentration of more than $10^{8}$ cfu/g of Shewanella putrefaciens is required for production of a TMA level normally found in spoiled fish. This suggests that there could be another type of bacterium in fish, not involved in the spoilage of unpacked fish, which is resistant to $60 \% \mathrm{CO}_{2}$, is not $\mathrm{H}_{2} \mathrm{~S}$-producing, and shows a high TMAO-reducing capacity. This bacterium could be Photobacterium phosphoreum.
\end{abstract}

* Corresponding author. Tel: +3292646177 ; fax +3292255510 . 
Keywords: Modified atmosphere packaging; Spoilage flora; Total volatile bases (TVB); Trimethylamine (TMA)

\section{Introduction}

Following early reports that carbon dioxide enriched atmosphere prolongs the market life of fish (Coyne, 1932; Shewan, 1950), considerable research has been done to show that modified atmosphere packaging (MAP) extends the shelf-life of fish and fishery products (Statham, 1984; Farber et al. 1990; Stammen et al., 1990). Carbon dioxide is especially effective in inhibiting the typical $\mathrm{H}_{2} \mathrm{~S}$-producing spoilage microflora (Jensen et al., 1980)

The microbial flora of fish from sea water consists of Gram-negative, psychrotrophic, aerobic or facultative anaerobic bacteria: Pseudomonas, Alteromonas, Shewanella, Moraxella, Acinetobacter, Flavobacterium, Cytophaga and Vibrio (Dehevere and Voets, 1974; Gram et al., 1987; Huss, 1988). The most active of the spoilage bacteria are Shewanella putrefaciens (previously known as Alteromonas putrefaciens) and certain Pseudomonas, Vibrio and Aeromonas spp. (Shewan, 1977; Donald and Gihson, 1992). These bacteria are classified as $\mathrm{H}_{2} \mathrm{~S}$-producing bacteria that can he enumerated on the Iron Agar 3 selective media of Gram (Gram et al., 1987). Most of these bacteria are facultative anaerobic microorganisms. When oxygen levels are depleted, TMAO which is a characteristic part of the non protein nitrogen fraction (NPN) of the fish muscle (Huss, 1988), serves as a terminal electron acceptor for anaerobic respiration (Easter et al., 1983) and is reduced to trimethylamine (TMA).

The total volatile bases fraction (TVB) includes ammonia, monoethylamine, dimethylamine along with trimethylamine (TMA). TVB is part of the NPN fraction of the fish muscle as well. The residual by the subtraction of TMA from TVB is called formalin-bound volatile nitrogen (FBVN), according to the Dyer method for TMA determination (Dyer, 1945). This fraction of TVB can increase slightly during storage due to some reactions of autolysis and deamination. TMA and TVB are considered responsible for unpieasant 'fishy' odor.

Fresh cod normally has less than $20 \mathrm{mg} \mathrm{N} / 100 \mathrm{~g} \mathrm{TVB}$ and $3 \mathrm{mg} \mathrm{N} / 100 \mathrm{~g}$ TMA. When the level of TVB and TMA exceeds $35 \mathrm{mg} \mathrm{N} / 100 \mathrm{~g}$ and $15 \mathrm{mg}$ $\mathrm{N} / 100 \mathrm{~g}$ respectively, the fish is considered spoiled (Connell and Shewan, 1980; Huss, 1988).

In this study modified atmosphere packaging was applied on fresh cod. Four different gas mixtures were used. In all four cases the proportion of $\mathrm{CO}_{2}$ was at the relatively high level of $60 \%$. The proportion of oxygen was set at $10,20,30$ and $40 \%$, respectively. The objective was to examine the inhibitory effects of $\mathrm{CO}_{2}$ on the microflora of the cod and to investigate the production of TVB-TMA in relation to a variable availability of oxygen. 


\section{Materials and methods}

\subsection{Sample preparation}

Fresh cod fillets (Gadus morhua) were divided in portions of $100 \mathrm{~g}$ each, and 3 portions were placed in polypropylene (PP) trays $(15 \mathrm{~cm} \times 10 \mathrm{~cm} \times 5 \mathrm{~cm})$. The trays were then introduced in $25 \mathrm{~cm} \times 35 \mathrm{~cm}$ plastic bags with high oxygen barrier (Sidamil, UCB Transpac, Belgium). The plastic bags are made out of PVDC, laminated with polyester, and have a gas-permeability of $6 \mathrm{cc} / \mathrm{m}^{2} / 24 \mathrm{~h}$ for $\mathrm{O}_{2}, 2$ $\mathrm{cc} / \mathrm{m}^{2} / 24 \mathrm{~h}$ for $\mathrm{N}_{2}$ and $1.5 \mathrm{cc} / \mathrm{m}^{2} / 24 \mathrm{~h}$ for $\mathrm{CO}_{2}$ at $25^{\circ} \mathrm{C}$ and $100 \% \mathrm{RH}$. The bags were filled and sealed with an A-300, Downers grave (CVP Systems Inc.), packaging set. The following mixtures were used: $60 \% \mathrm{CO}_{2}, 10 \% \mathrm{O}_{2}, 30 \% \mathrm{~N}_{2}$ (G613), $60 \% \mathrm{CO}_{2}$, $20 \% \mathrm{O}_{2}, 20 \% \mathrm{~N}_{2}(\mathbf{G 6 2 2}), 60 \% \mathrm{CO}_{2}, 30 \% \mathrm{O}_{2}, 10 \% \mathrm{~N}_{2}(\mathbf{G 6 3 1}), 60 \% \mathrm{CO}_{2}, 40 \% \mathrm{O}_{2}, 0 \%$ $\mathrm{N}_{2}$ (G640). One volume of modified atmosphere ( $300 \mathrm{ml}$ per $300 \mathrm{~g}$ of fish) was added. Five samples of each gas mixture were stored at $6^{\circ} \mathrm{C}$ and $95 \% \mathrm{RH}$. The day the samples were prepared was considered as day 0 . At days $0,3,4,5$, 6 , and 7 chemical and microbiological analysis were performed.

\subsection{Microbiological analysis}

Thirty g of fish sample were collected aseptically in a stomacher bag and diluted ten times with sterile physiological saline-peptone solution (PS, $0.85 \% \mathrm{NaCl}, 0.1 \%$ peptone, $\mathrm{pH} 7$ ). After homogenizing in a Colworth Stomacher 400 (Seward Laboratory, London, England, UK), a series of tenfold dilutions was made in PS for microbiological analysis.

Total number of bacteria was determined as poor plate counts in PCA (Plate Count Agar, Oxoid CM463) after incubating for 5 days at $25^{\circ} \mathrm{C}$. The number of anaerobic bacteria was determined as poor plate counts in PCA but incubation was carried out in an anaerobic jar, for 5 days at $25^{\circ} \mathrm{C}$. Lactic acid bacteria were determined as poor plate counts in MRS agar (Oxoid CM361) with a cover layer after 5 days at $30^{\circ} \mathrm{C}$. Enterobacteriaceae were determined as poor plate counts in Violet Red Bile Glucose Agar (VRBGA, Oxoid CM485) after $24 \mathrm{~h}$ incubation at $37^{\circ} \mathrm{C}$. Hydrogen sulfide-producing bacteria were counted as black colonies of poor plate counts in Iron Agar Lyngby (Oxoid CM867) with cover layer after 5 days at $30^{\circ} \mathrm{C}$.

\subsection{Chemical analysis}

Before opening, the gas composition of the bags was determined with a Servomex gas analyzer (Food Package Analyzer, Series 1400).

Immediately after opening, $10 \mathrm{~g}$ from each bag was aseptically collected and placed in the inner flask of the Antonacopoulos steam-distillation apparatus (Antonacopoulos, 1960). Steam distillation for the collection of the TVB was carried out according to the method of Lüecke and Geidel (Vyncke, 1969). The distillate was titrated by $0.1 \mathrm{~N} \mathrm{H}_{2} \mathrm{SO}_{4}$ (p.a.) with methyl-red as indicator. Before the 
addition of the indicator in the distillate, $2 \mathrm{ml}$ were collected for trimethylamine analysis. TMA was determined using the Dyer spectrophotometric method (Dyer, 1945). The absorbance at $410 \mathrm{fm}$ was measured with a Bausch and Lomb, Spectronic 1001 spectrophotometer.

Next, $100 \mathrm{~g}$ of each bag was blended separately and $\mathrm{pH}$ was measured in the blended fish muscle with an Ingold sharp point electrode connected to a Knick, Multi Climatic, Microprocessor pH-meter.

\section{Results}

\subsection{Microbiological analysis}

Fig. 1 shows a poor increase in the number of the total aerobic bacteria for all of the gas atmospheres applied. Storage at low temperature $\left(6^{\circ} \mathrm{C}\right)$ in combination with the presence of $60 \% \mathrm{CO}_{2}$ inhibits bacterial growth. No difference can be observed between the total aerobic counts for the different gas mixtures.

The number of anaerobic bacteria did not increase during the first 3 days (Fig. I), which can be attributed to the inhibitory effect of $\mathrm{CO}_{2}$ at low temperature $\left(6^{\circ}\right)$. From the fourth day on, an exponential increase of the anaerobic count was observed and subsequently it reached the same levels as for the total

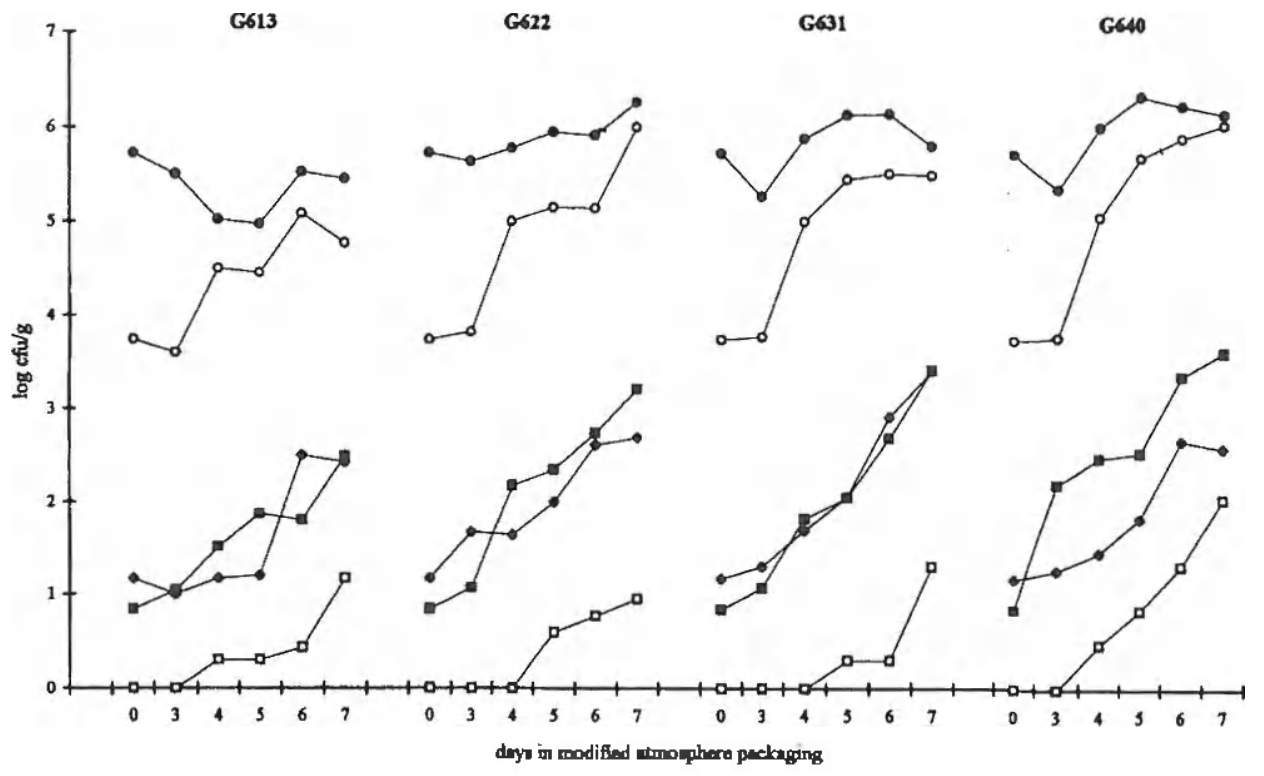

Fig. 1. Bacterial plate counts (aerobic - - anaerobic $-\mathrm{O}$ - lactic acid bacteria - $\mathrm{H}_{2} \mathrm{~S}$-producing bacteria - $-\rightarrow$, Enterobacteriaceae - - -) on cod fillets packed under modified atmosphere (G613, G622, G631, G640) for 7 days. 
aerobic hacterial plate count at the seventh day. In the gas atmosphere G613, the increase of the anaerobic count was slower compared to the other atmospheres.

Lactic acid bacteria increased by 1-2 logarithmic units during 7 days in modified atmosphere packaging (Fig. 1). There is no difference in the lactic acid bacteria plate counts among the gas mixtures.

Hydrogen sulfide producing bacteria increased 2-3 log units in 7 days starting from the third day, except in the G640 atmosphere where there was an early outgrowth (Fig. 1). In no case the count of $\mathrm{H}_{2} \mathrm{~S}$-producing bacteria reached the spoilage limit of $10^{7} \mathrm{cfu} / \mathrm{g}$.

Incidence of Enterobacteriaceae was observed only after 4 days in the G613 and $\mathrm{G} 640$ atmosphere and after 5 days in $\mathrm{G} 631$ and G622 atmosphere (Fig. 1). Further growth was very slow. On the seventh day $10 \mathrm{cfu} / \mathrm{g}$ were present, except for the G640 atmosphere where growth was slightly faster and $100 \mathrm{cfu} / \mathrm{g}$ were counted finally (Fig. 1)

\subsection{Chemical analysis}

The proportion of $\mathrm{CO}_{2}$ in the atmosphere of the packages decreased until day 4 because of diffusion into the fish muscle (results not shown). From day 5 on, the content of $\mathrm{CO}_{2}$ increased again due to bacterial and enzymatic activity. Reciprocally to the $\mathrm{CO}_{2}$ content the proportion of $\mathrm{O}_{2}$ increased up to day 4 . Due to respiration of bacteria the proportion of $\mathrm{O}_{2}$ decreased later on.

The production of TVB was continuous in all atmospheres (Fig. 2). TMA, like TVB, is continuously produced during 7 days storage in MAP. From day 5 on, the rate of TMA production differs depending on the packaging atmosphere and it can be seen that higher levels of oxygen delay the production of TMA.

As a consequence of TVB production a slight increase in $\mathrm{pH}$ was noticed during the first 4 days of storage (Table 1). Diffusion of the $\mathrm{CO}_{2}$ in the fish muscle shows a certain counter effect on the $\mathrm{pH}$ increase by TVB production, resulting in a stabilization of the $\mathrm{pH}$ around 6.7 .

\section{Discussion}

Despite the fact that the total number of bacteria, determined in PCA at $25^{\circ} \mathrm{C}$, was relatively high at day $0\left(\sim 10^{6} \mathrm{cfu} / \mathrm{g}\right)$ it did not increase significantly and remained below $10^{7} \mathrm{cfu} / \mathrm{g}$ (Fig. 1). The carbon dioxide atmosphere, with variable proportions in oxygen, can be considered effectively inhibitory on the total aerobic flora. This composition of atmosphere is in accordance to most recommendations and practices for 'seafood' suggesting an initial concentration of $\mathrm{CO}_{2}$ between 30 and $60 \%$ (Davis, 1993). Tiffney and Mills (1982) found that $\mathrm{O}_{2}$ actually increased the shelf life of white fish in controlled atmosphere. Robertson (1993) proposes a mixture of $30 \% \mathrm{O}_{2}-40 \% \mathrm{CO}_{2}-30 \% \mathrm{~N}_{2}$ for non fatty fish and $40 \% \mathrm{CO}_{2}-60 \% \mathrm{~N}_{2}$ for fatty fish. Sacks and Gore (1987) included $40 \%$ 


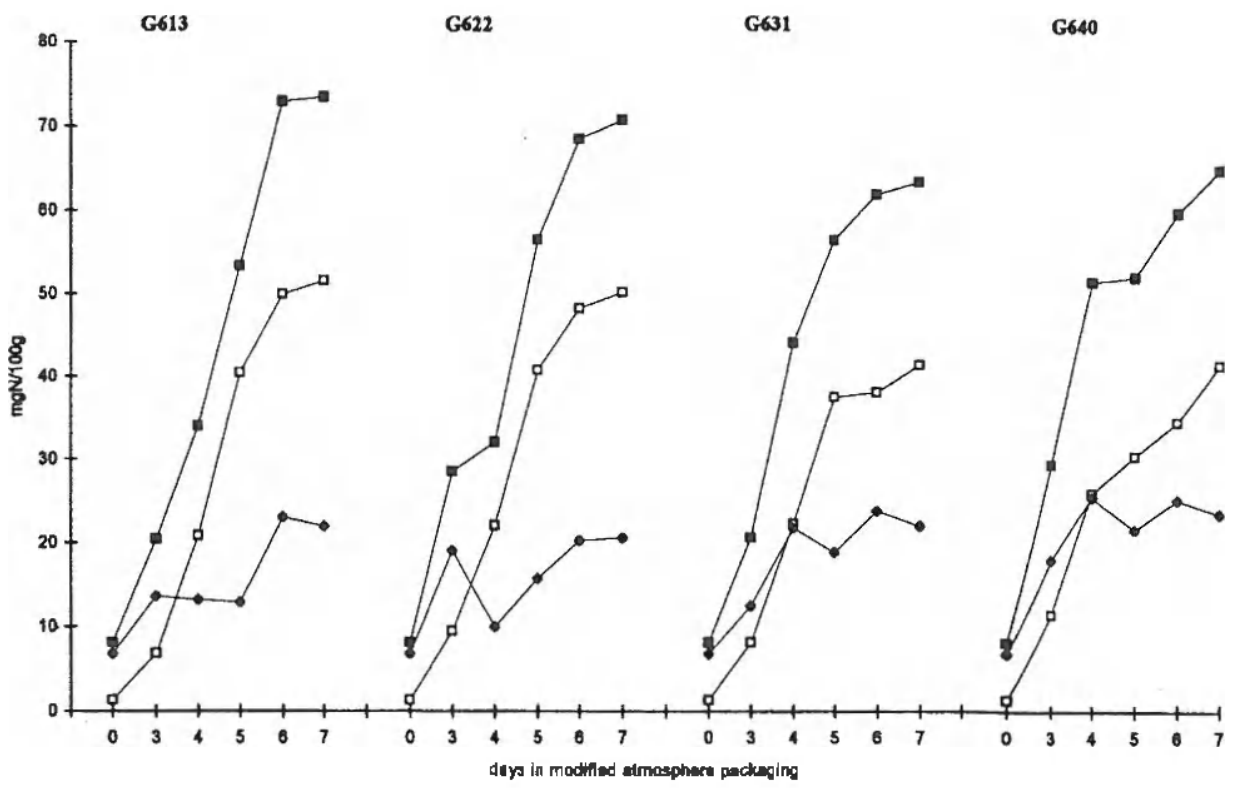

Fig. 2. TVB (-口-), TMA (- - - - ) and FBVN (- -) production in cod fillets packed under modified atmospheres $(\mathrm{G} 613, \mathrm{G} 622, \mathrm{G} 631, \mathrm{G} 640)$ for 7 days. (FBVN = TVB-TMA).

$\mathrm{O}_{2}$ and $60 \% \mathrm{CO}_{2}$ as an alternative for white fish. On the contrary, Kimber (1984) declared that fish requires an inert mixture of $\mathrm{CO}_{2}$ and $\mathrm{N}_{2}$, and that care is taken to remove any $\mathrm{O}_{2}$.

However, significant production of TVB and TMA, which contributes to a negative effect on the organoleptic quality of the fish fillet, was noticed. Increase in TVB is mainly ascribed to TMA production rather, than to the production of other volatile bases (Fig. 2). There are not many references on the relation of the gas mixture to the spoilage by TMA production. According to Easter (1982) oxygen exerts an inhibitory effect on the TMAO-reductase activity of Alteromonas spp., while $\mathrm{CO}_{2}$ has an indirect inhibitory effect on the same enzyme by reducing the $\mathrm{pH}$ to $\sim 6$. Easter et al. (1982) proved that TMAO reductase has an optimum activity

Table 1

Changes in $\mathrm{pH}$ values of cod fillets stored for 7 days under modified atmosphere packaging

\begin{tabular}{lllll}
\hline Days & G613 & G622 & G631 & G640 \\
\hline 0 & 6.33 & 6.33 & 6.33 & 6.33 \\
3 & 6.48 & 6.53 & 6.40 & 6.41 \\
4 & 6.74 & 6.60 & 6.70 & 6.93 \\
5 & 6.76 & 6.66 & 6.79 & 6.69 \\
6 & 6.70 & 6.63 & 6.68 & 6.71 \\
7 & 6.64 & 6.69 & 6.75 & 6.69 \\
\hline
\end{tabular}


at $\mathrm{pH}$ 6.8. As it is demonstrated in Table 1 , the $\mathrm{pH}$ of cod increased from the initial $\mathrm{pH}$ of 6.33 to $\sim 6.7$, enhancing the activity of TMAO-reductases. Therefore Vilemure et al. (1986) suggested that the storage time of cod fillets, stored in $25 \% \mathrm{CO}_{2}-75 \% \mathrm{~N}_{2}$ controlled atmosphere at $0^{\circ} \mathrm{C}$, should be restricted to 7 days on the basis of TVB production. Davis (1990) used a gas mixture of $40 \%$ $\mathrm{CO}_{2}-30 \% \mathrm{O}_{2}-30 \% \mathrm{~N}_{2}$ for cod fillets stored at 0,5 and $10^{\circ} \mathrm{C}$ and observed the TMA score increasing rapidly after 11,4 and 3 days respectively.

In Fig. $I$ it can be seen that the aerobic flora shows a facultative anaerobic behaviour and is resistant to $\mathrm{CO}_{2}$. Lactic acid bacteria are carbon dioxide tolerant too, but referring to Hanna (1992) their growth in fish is limited for the first 14 days. The inhibition of Enterobacteriaceae by carbon dioxide has been reported several times in the past by other researchers (Gill and Tan, 1979; Coyne, 1933; Haines, 1993). A major part of the $\mathrm{H}_{2} \mathrm{~S}$-producing bacteria is facultative anaerobic and has the ability of reducing TMAO to TMA (Huss, 1988). Hydrogen sulfide producing bacteria represent only a small part of the total flora in cod fillets packed in $\mathrm{CO}_{2}$-atmosphere (Fig. 1).

By comparing the four types of gas atmosphere $\mathrm{G} 640$ atmosphere, $\left(60 \% \mathrm{CO}_{2}\right.$, $40 \% \mathrm{O}_{2}$ ) can be considered as the most effective for the inhibition of TMA production. The higher oxygen availability in this atmosphere leads to a low utilization of TMAO as a secondary electron acceptor. However, it has to be noted that the application of a G640 atmosphere can not entirely prevent the spoilage by TMA. Application of higher oxygen levels could possibly reduce the production of TMA but this will be on the expense of the carbon dioxide level and the antimicrobial activity of the latter.

A total aerobic plate count at $25^{\circ} \mathrm{C}$ of a $10^{6} \mathrm{cfu} / \mathrm{g}$, combined with the presence of only a $10^{3} \mathrm{cfu} / \mathrm{g}$ of $\mathrm{H}_{2} \mathrm{~S}$-producing bacteria, which are normally considered as TMAO-reducing organisms in fish, cannot explain the strong increase in TMA. Indeed, a high cell concentration of more than $10^{R} \mathrm{cfu} / \mathrm{g}$ of Shewanella putrefaciens is required for production of a TMA level normally found in spoiled fish (Dalgaard, 1995). This suggests that there could be another type of bacterium in fish, not involved in the spoilage of unpacked fish, which are resistant to $60 \%$ of $\mathrm{CO}_{2}$, are not $\mathrm{H}_{2} \mathrm{~S}$-producing: and show a high TMAO-reducing capacity per cell unit. This conclusion is in agreement with the findings of Dalgaard et al. (1993) and Dalgaard (1995) suggesting that large cells of Photobacterium phosphoreum could be responsible for the TMA production and hence for the spoilage of modified atmosphere packed fish. On average, cells of $P$. phosphoreum produce several times more TMA than cells of S. putrefaciens (Dalgaard, 1995)

It can be concluded that packaging of cod fillets in modified atmosphere, containing $60 \% \mathrm{CO}_{2}$ and $40 \% \mathrm{O}_{2}$ (i part of gas and 1 part of fish), and storing at $6^{\circ} \mathrm{C}$ have an inhibiting effect on the growth of the normal TMA- and $\mathrm{H}_{2} \mathrm{~S}$ producing flora (Shewanella putrefaciens). However, these conditions are less effective on the inhibition of the growth and activity of the TMAO-reducing large cells of Photohacterium phosphoreum, which are not $\mathrm{H}_{2} \mathrm{~S}$-producing, and show a high resistance against $60 \% \mathrm{CO}_{2}$. In order to decrease the TMAO-reduction by $P$. phosphoreum $\mathrm{O}_{2}$ can be added in the packaging atmosphere. 


\section{References}

Antonacopoulos, N. (1960). Verbesserte Apparatur zur Quantitativen Destillations Wasserdampffluchtiger Stoffen. Zeitschrift Lebensmitteln - Untersuch. v. Forsch. 113, 113.

Connell, J.J. and Shewan, J.M. (1980) Sensory and non-sensory assessment of fish. In: 1. Connell (editor), Advances in Fish Science and Technology, Fishing News Books, Farnham, pp. 55-56

Coyne, F. (1932) The effect of carbon dioxide on bacterial growth with special reference to the preservation of fish. Part I, J. Soc. Chem. Ind. 51, 119T-121T.

Coyne, F. (1933) The effect of carbon dioxide on bacterial growth. Proc. R. Soc. Ser. B 113, 196-217.

Dalgaard, P. (1995) Qualitative and quantitative characterization of spoilage bacteria from packed fish. lnt. I. Food Microbiol. 26, 319-333.

Dalgaard, P., Gram, L. and Huss, H.H. (1993) Spoilage and shelf-life of cod fillets packcd in vacuum or modified atmospheres. Int. J. Fond Microbiol. 19, 283-294.

Davis, H.K. (1990) Some effects of modified atmosphere packaging gases on fish and chemical tests for spoilage. In: Commission C2, Int. Inst. Refrig., 'Chillinng and Freezing of New Fish Ptoducts', Aberdecn 1990-3, pp. $201-207$.

Davis, H.K. (1993) Chapter 9: Fish. In: R.T. Parry (editor), Principles and Applications of Modiffed Atmosphere Packaging of Foods, Blackje, Glasgow.

Debevere, J.M. and Voets, J.P. (1974) A rapid selective medium for the determination of trimethylaminenxide-reducing bacteria. Zeitschrift fur Allg. Microbiol. 14, 655-658

Donald, B. and Gibson, D.M. (1992) Preliminary observations on the fora of fresh vacuum packed salmon steaks. In: H.H. Huss et al. (editors), Quality Assurance in the Fish Industry, Conference Proceedings, Elsevier, Amsterdam.

Dyer. W.J. (1945) Amines in fish muscle. I. Colorimetric deternination of trimetlylamine as the picrate salt. J. Fish. Res. Board Can. 8, 314.

Easter, M.C. (1982) Trimethylamine- $N$-oxide reduction by Alteromonas spp. Ph.D. Thesis, Robert Gordon's Institute of Technology, Aberdeen, UK.

Easter, M.C., Gibson, D.M. and Ward, F.B. (1982) A conductance method for the assay and study of bacterial trimethylamine oxide reduction. I. Appl. Bacteriol. 52, 357-365.

Easter, M.C., Gibson, D.M. and Ward, F.B. (1983) The induction and lncation of trimethylamine- $N$-oxide reductase in Alteromonas sp. NCMB 400. J. Gen. Microbiol. 129, 3689-3696

Farber, J.M., Warburton, D.W., Gour, L. and Milling, M. (1990) Micrabiological quality of foods packaged under modified atmospheres. Food Microbiol. 7, 327-334

Gill, C.O. and Tan, K.H. (1979) Effect of carbon dioxide on growth of Pseudamonas furoescen. App!. Environ. Microbiol. 28, 237-240.

Gram, L., Trolle, G. and Huss, H.H. (1987) Detection of specific spoilage bacteria from fish stored at low $\left(0^{\circ} \mathrm{C}\right)$ and high $\left(20^{\circ} \mathrm{C}\right)$ temperatures. Int. J. Fond Micrabiol. 4, 65-72.

Haines, R.B. (1993) The influence of carbon dioxide on the rate of multiplication of certain bacteria as judged by viable plate counts. J. Soc. Chem. lnd. 52, I3T-17T.

Hanna, S. (1992) Rapid microbial method and fresh fish quality assessment. In: G.M. Hall (editor), Fish Processing Technology, Chapman and Hall, New York

Huss, H.H. (1988) Fresh fish - quality and quality changes. FAO, Danish International Development Agency, Rome, Sagraf.

Jensen, M.H., Petersen, A., Røge, E.H. and Jepsen, A. (1980) Chilled and frozen storage. Storage of chilled cod under vacuum and at various concentrations of carbon dioxide. In: J.J. Conell and staff of Torry Research Station (editors), Advances in Fish Science and Technology, Fishing News Books. London.

Kimber, A. (1984) Update on the gas flush pack. Food Manuf. 59, 22-25.

Robertson, G.L. (1993) Food Packaging: Principles and Practice, Marcel Dekker, New York

Sacks, B. and Gore, A. (1987) Gas packaging - techniques and trends. Food Rev. June/July, 26-39.

Shewan, J.M. (1950) Improving the quality of 'white' fish by the use of gas storage. Fishing News 1946 , 14. 
Shewan, J.M. (1977) The bacteriology of fresh and spoiling fish and the biochemical changes induced by bacterial action. Conference on the Handling, Processing and Marketing of Tropical Fish, Tropical Products Institute, London. Proceedings, pp. 51-66.

Stammen, K., Gerdes, D. and Caporaso, F. (1990) Modified atmosphere packaging of sea food. CRC Rev. Food Sci. Nutr. 29, 301-303.

Siatham, J. (1984) Modified atmosphere storage of fisheries' products, the state of the art. Food Technol. Aust. 36, 233-239.

Tiffney, P. and Mills, A. (1982) Stcrage trials of controlled atmosphere packaged fish products. Tech Rep. No. 191, Sea Fish Industry Authority, UK.

Vilemure, G., Simard, R.E. and Picard, G. (1986) Bulk storage cod fillets and gutted cod (Gadus morhua) under carbon dioxide atmosphere. J. Fond Sci. 5!, 317-320

Vyncke, W. (1969) Bijdrage tot de studic van extraheerbare stiksctofverbindingen in doornhaai (Squalus acanthiss L.) en de evolutie ervan tijdens het bewaren in ijs. Doctorate Thesis, University of Ghent, Belgium. 